\title{
A cross sectional study on constraints in broiler farming at Perambalur district of Tamil Nadu
}

\author{
S. PRAVEENA AND M. BOJIRAJ
}

Author for Corresponding -

\section{S. PRAVEENA}

Department of Social Sciences,

(Agribusiness Management),

Thanthai Roever Institute of

Agriculture and Rural

Development (T.N.A.U.)

Valikandapuram, PERAMBALUR

(T.N.) INDIA

Email : sspriyamba@gmail.com

See end of the article for

Coopted authors'

\begin{abstract}
The poultry farming plays an important role in the rural economy of India. Broiler farming is faced with many challenges including diseases, predators and inadequate feed. The study was conducted in 30 respondents (30 Poultry farmers) with preformed questionnaire to analysis the constraints faced by the farmers in broiler farming using the Garrett ranking method. In the present study found that constraints in terms of marketing of chicks, non-remunerative price was the main constraints followed by transportation problem, Disease attacked timerumorregarding price fluctuation and late payment. A constraint faced by the farmers in production of chicken water scarcity is the main problem followed by high temperature, mortality problem, availability of labour and feed. Among the Social and natural problems outbreaks of disease was the main problem followed by predator animal likes cats, $\mathrm{dog}$, and pollution of environment. The broiler farming is a profitable venture and has a bright future in the study area of Perambalur district of Tamil Nadu for reducing the constraints faced by the poultry farming community.
\end{abstract}

KEY WORDS...... Broiler farming, Constraints, Non-remunerative price, Water scarcity, Disease out break

HOW TO CITE THIS ARTICLE - Praveena, S. and Bojiraj, M. (2017). A cross sectional study on constraints in broiler farming at Perambalur district of Tamil Nadu. Asian J. Animal Sci., 12(2): 120-123. DOI : 10.15740/HAS/TAJAS/12.2/120-123.

ARTICLE CHRONICLE - Received : 03.06.2017; Revised : 06.11.2017; Accepted : 20.11.2017 